\title{
Configurations of Capitals of an Innovative Ecosystem in the Economy of Knowledge
}

\author{
Daria Lanskaya $^{1,{ }^{*}}$ Boris Ryakhovsky ${ }^{1, \mathrm{a}}$ Anastasiya Yakovlenko ${ }^{1, \mathrm{~b}}$
}

\author{
${ }^{1}$ Department of General, Strategic Management and Business Processes, Kuban State University, Krasnodar, Russia \\ ${ }^{a}$ Email: yahovsky@oldspring.ru \\ ${ }^{\mathrm{b}}$ Email: yakovlenko_nastya@mail.ru \\ *Corresponding author. Email: lanskayaDV@yandex.ru
}

\begin{abstract}
The paper examines the problem of configuring tangible and intangible capitals in the internal space of the innovation ecosystem of the knowledge economy, adequate to the strategy being implemented. The purpose of the paper is to study the relationship between tangible and intangible capitals and a fractal approach to modeling their configurations, which is achieved by solving a set of problems. An approach to modeling the capitalogram of a corporation of the knowledge economy is being developed using modern intelligent modeling tools and visual presentation of the results.
\end{abstract}

Keywords: tangible and intangible capital, captalogram, complementarity, competitiveness, configuration of capitals, strategizing

\section{INTRODUCTION}

Real and intangible capital is important in ensuring the competitiveness of any economic system, including the environmental innovation ecosystem of the region (hereinafter - corporations)

The problem of configuring tangible and intangible capitals in the internal space of the innovation ecosystem of the knowledge economy, adequate to the strategy being implemented, is relevant and relatively new for the theory and practice of managing the process of forming and developing its competitiveness in the market of innovation.

Modern competitive management of various complex and large economic systems is impossible without a systematic analysis of factors, informed decisions, preliminary testing on simulation models and estimates of expected results [2], [3]. This explains the relevance of this exploratory study.

The purpose of the paper is to study the relationship between tangible and intangible capitals and a fractal approach in modeling their configurations that are adequate to the peculiarities of the strategy of formation and development of a corporation of the knowledge economy in the course of strategizing its competitiveness.

This goal is achieved by solving a set of tasks:

- identification of evolutionary laws that provide a meaningful modern content of the concept of "capital";
- determination of conditions for achieving harmony of capital elements;

- development of a method for modeling the capitalogram of a corporation of the knowledge economy based on the use of intelligent modeling tools.

As a hypothesis of the study, a formula is proposed: the configurations of the capitals of a corporation of the knowledge economy can have a certain design, which is determined by the way of interaction of all capitals allocated by intellectual human capital in the course of strategizing, mechanisms of inclusion in the reproduction process and harmonization of interests of subjects of innovation.

\section{MODERN SEMANTICS OF CAPITAL}

The current stage of development largely changes the meanings of long-known concepts. The gradual development of society paved the way for a new expansive point of view on capital [4]. Capital characterizes as the total value of assets in monetary, material and non-material forms, invested in the formation of assets of the corporation [5], [6].

Intellectual activity, knowledge and technology are becoming factors in creating add value, competitiveness and economic development of organizations [7]. In this regard, the processes of intellectualization of the economy significantly change the interpretation of capital from an exclusively material asset to a set of objects of a non-material nature. Capital today is not 
only finance and tangible resources, but also knowledge, experience, skills, intelligence of corporation and information. This is reflected in the structure and content of the production function of the new format [6], [8]. As its arguments - capital, they began to consider:

- technological, natural resource, financial capital. There is an unambiguous idea about this group of capitals;

- institutional, organizational and informational capital;

- intellectual or cognitive capital, cultural, mental capital [7].

Intellectual capital by its elements is present in the structure of other capitals [9]. Each organization must have its own strategy for the development of intellectual resources in order to have a market advantage. The value of intellectual capital increases when it is embodied in goods, services and business processes. By itself, intellectual capital, not combined with other capitals, does not give the important result that is possible in the knowledge economy [10].

Therefore, mechanisms of involvement in the reproduction process in all forms of capital and their elements for the development of the organization are important.

\section{STRUCTURE OF THE TOTAL CAPITAL OF THE ECONOMIC SYSTEM}

The effective and successful functioning of the corporation is reduced to the minimum required amount of capital of each type and, in general, the total capital, which is understood as the total cost of factors of production (tangible and intangible assets) - property objects or an advanced asset that are used to create and generate profit [4], [11], [12].

V.V. Ermolenko introduced the term "capitalogram" into scientific circulation - it is "a combination of a material component, financial capital and a virtual component (intangible types of capital), as well as social and communicative relations, institutions (norms, traditions, procedures), organizations (experience, culture, models ), created with the active participation of human and the special role of intellectual capital, which underlie the vertical of power and competitive advantages of the economic system "[7]. Capital can be broken down into component parts, some of which will be dominant, while others will act as secondary, but at the same time with a fundamental role.

G.B. Kleiner, within the framework of the systemintegration theory in the internal space of the enterprise, distinguishes the following types of capital as components, which can be represented in the form of the so-called "sandwich pyramid" ("Fig. 1") [2].

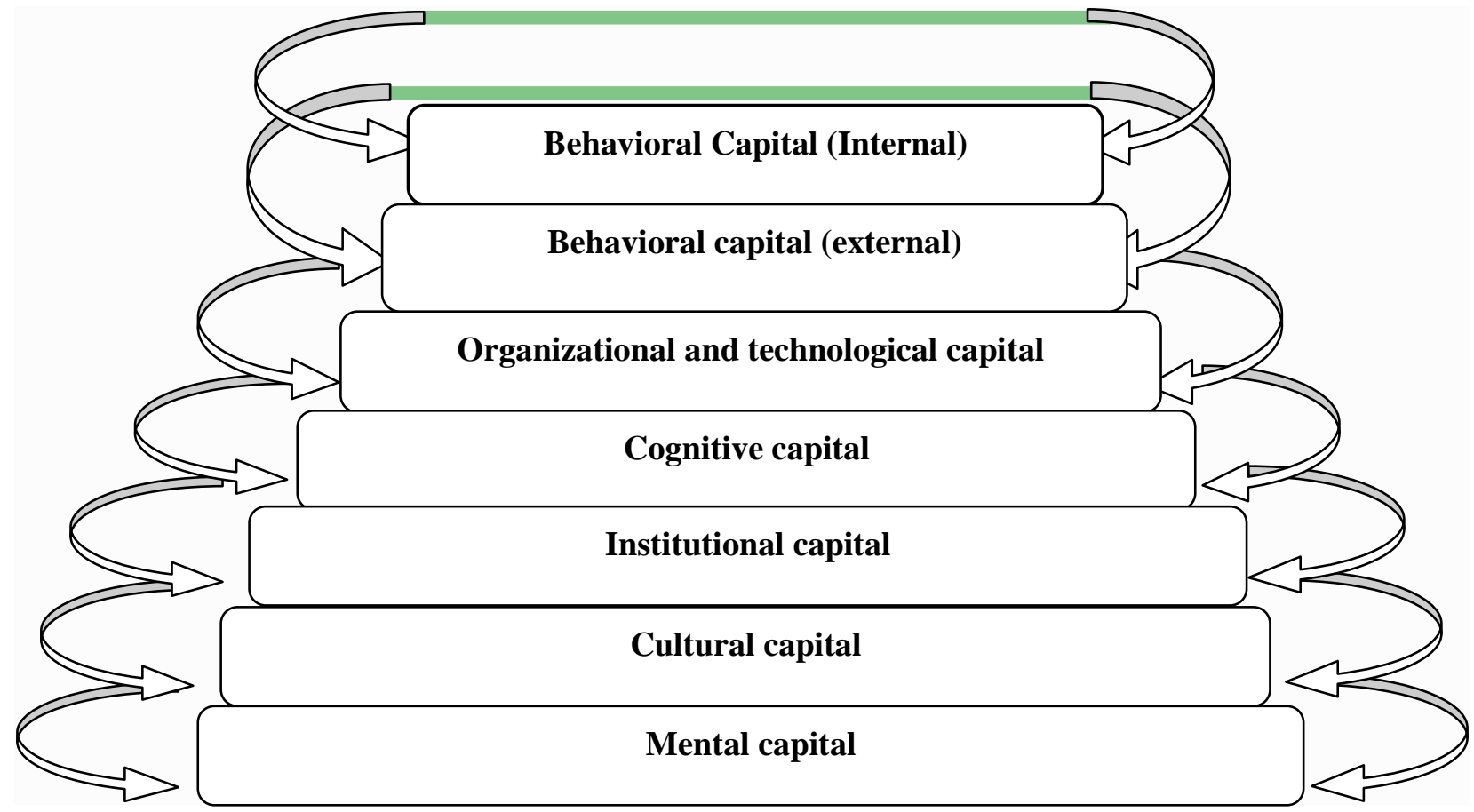

Fig. 1. "Sandwich pyramid" of types of corporation capital (according to G. Kleiner).

The peculiarity of the proposed concept is "the formation in the structure of the corporation of certain configurations of capital (capitalograms), which are "lattices" ("Fig. 2"), consisting of: 
- "core" of capital, including the material component, financial, human and technological capital;
- capitals that form a sphere of mental, cultural, informational, intellectual and institutional capitals "[10].

\section{Financial, human, technological capitals}

\section{Cultural, informational, intellectual, institutional capitals}

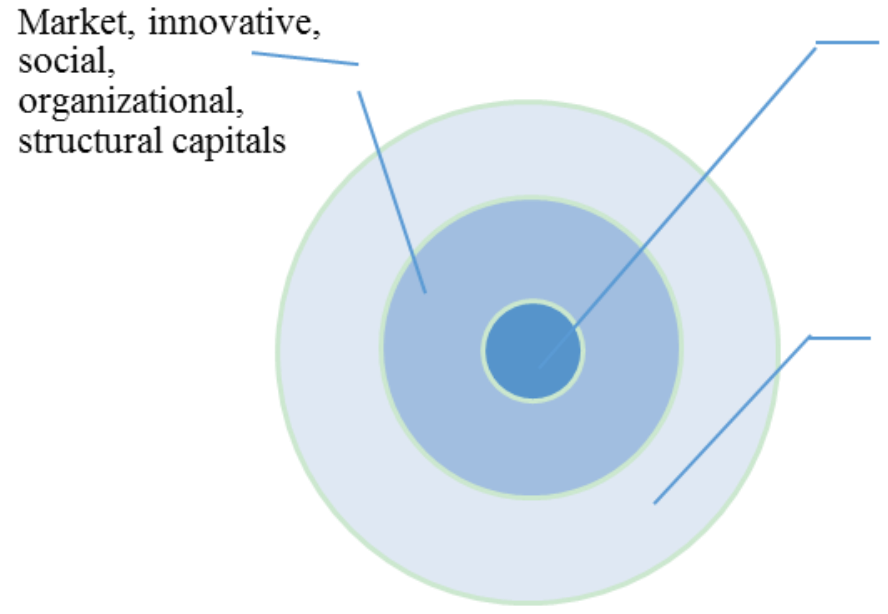

Fig. 2. Capital configuration.

J. Galbraith singled out among the capital in the corporation a special "intellectual core", which plays an important role in solving two problems:

- ensures adaptation to a turbulent external environment, self-organization and selfdevelopment of the entire system of corporate relations;

- ensures the reproduction of the total capital [1], [3], [7], [12].

The formation of an "intellectual core" in the corporation of the knowledge economy creates conditions for the implementation of strategic management, operational problem solving, following internal and external trends in the development of the economic system. Each corporation forms an "intellectual core", which is specified by its nature, functional and structural features [7].

\section{FORMS OF CAPITAL AND DESCRIPTION OF \\ CAPITALOGRAM}

Based on the fundamental theories of capital, it is possible to represent the structure of capital by dividing it into its component parts - elements ("Table I"). Their key feature is that they are not fixed, but are in constant motion depending on the chosen strategic line of development of a particular corporation.

The growing influence of non-material factors on the position of the corporation and the change in the structuring of capital reflects the natural evolution of the transition from the classical concept of capital to the post-industrial one, and from it to the newest concept.
In the conditions of flexible production processes, the release of final products in the internal environment of a corporation is carried out thanks to rapidly changing combinations of capital. "Harmony is a rational combination of factors in the business process for a corporation" [14].

J.B. Clark proposed to single out the "dominant factor (capital)" in the formation of a harmonious capital combination over all the capitals participating in the combination [3], [13], [14]. 
TABLE I. CAPITAL STRUCTURE OF THE CORPORATION

\begin{tabular}{|c|c|c|c|}
\hline o. & Capital type & Elements & Indicators \\
\hline & Intellectual capital & $\begin{array}{l}\text { - knowledge; } \\
\text { - experience; } \\
\text { - objects of intellectual property; } \\
\text { - technical support and software; } \\
\text { - information }\end{array}$ & $\begin{array}{l}-\% \text { of employees engaged in R\&D; } \\
-\% \text { of employees with a scientific degree; } \\
\text { - the number of registered patents; } \\
\text { - the degree of novelty of software and hardware }\end{array}$ \\
\hline & Financial capital & $\begin{array}{l}\text { - monetary resources; } \\
\text { - valuable security } \\
\text { - investments } \\
\text { - loan obligations } \\
\text { - intangible assets }\end{array}$ & $\begin{array}{l}-\% \text { of profitability; } \\
\text { - the proportion of earnings per share; } \\
-\% \text { of investments in fixed assets; } \\
\text { - costs of innovations; } \\
\text { - credit load in relation to profit }\end{array}$ \\
\hline & Structural capital & $\begin{array}{l}\text { - organizational structure; } \\
\text { - development strategy; } \\
\text { - management system; } \\
\text { - information resources and } \\
\text { technologies; } \\
\text {-corporate culture }\end{array}$ & $\begin{array}{l}\text { - the degree of employee satisfaction in } \% \text {; } \\
\text { - the level of technical equipment of the } \\
\text { personnel; } \\
\text { - the share of the number of management } \\
\text { personnel in the total number of employees; } \\
\text { - the volume of production; } \\
\text { - efficiency of execution of decisions }\end{array}$ \\
\hline & Human capital & $\begin{array}{l}\text { - human abilities; } \\
\text { - labor resources; } \\
\text { - knowledge and skills; } \\
\text { - motivation to work; } \\
\text { - system of values }\end{array}$ & $\begin{array}{l}\text { - the average work experience of employees in } \\
\text { the corporation; } \\
\text { - share of expenses for personnel development } \\
\text { and training; } \\
\text { - the level of labor productivity; } \\
\text { - the proportion of employees with an appropriate } \\
\text { educational level }\end{array}$ \\
\hline & Market capital & $\begin{array}{l}\text { - marketing strategy; } \\
\text { - market niche of the corporation; } \\
\text { - competitiveness; } \\
\text { - customer base; } \\
\text { - formed brand }\end{array}$ & $\begin{array}{l}\text { - the volume of total demand for the product } \\
\text { from the average client for the period; } \\
\text { - market share of the organization; } \\
\text { - the level of solvency of loyal customers; } \\
\text { - indicators of brand value growth in comparison } \\
\text { with the costs of its development }\end{array}$ \\
\hline & Innovation capital & $\begin{array}{l}\text { - innovative infrastructure; } \\
\text { - technology; } \\
\text { - investments; } \\
\text { - intellectual resources; } \\
\text { - innovations }\end{array}$ & $\begin{array}{l}\text { - the number of implemented innovative projects; } \\
\text { - R\&D expenses related to total sales; } \\
\text { - the amount of funds raised for innovation; } \\
\text { - the share of new technologies in total spending } \\
\text { on innovation }\end{array}$ \\
\hline & Institutional capital & $\begin{array}{l}\text { - a system of company } \\
\text { relationships; } \\
\text { - public institutions; } \\
\text { - range of consumers; } \\
\text { - company value system }\end{array}$ & $\begin{array}{l}\text { - dynamics of competitors' prices; } \\
\text { - the share of loyal customers; } \\
\text { - the number of partnerships; } \\
\text { - degree of interaction with state and local } \\
\text { authorities }\end{array}$ \\
\hline & Physical capital & $\begin{array}{l}\text { - material resources; } \\
\text { - equipment; } \\
\text { - means of production }\end{array}$ & $\begin{array}{l}\text { - depreciation ratio of fixed assets; } \\
\text { - the ratio of the total volume of marketable } \\
\text { products to the amount of material costs; } \\
\text { - equipment power per unit of time }\end{array}$ \\
\hline
\end{tabular}

In the knowledge economy, the structure of total capital expands significantly, giving rise to the problem of effective management of not only financial capital. Therefore, on this basis, it is possible to achieve harmony in the internal production environment of the corporation by building a capitalogram. The formation of capitalograms contributes to the solution of such problems in the internal space of the corporation as the ratio of the development strategy with the necessary set of factors for this; organization of actions on capitals, namely, the development of methods for assessing the completeness of the description, determination of the optimal configuration, formalization, modeling and management; assessment of competitiveness and potential risks.
As a rule, one or another configuration of capital depends on the following groups of factors: marketing, leadership positions, social policy, etc.

The importance of certain types of capital is changing. And it is necessary in a situational mode to correct and simulate new more adequate working capitalograms.

Thus, a harmonious configuration of capital should correspond to the situation and trends of changes in the external and internal environment. 


\section{Fractal REPRESENTATION OF TOTAL CAPITAL}

The idea of representing capital in the form of a system of elements that can flow from one capital to another suggests the application of the theory of fractals to the study of the total capital of a corporation (Fig 3). So, "a fractal is understood as a complex geometrical figure with the property of self-similarity, that is, composed of several parts, each of which is similar to the whole figure" [15].

Fractals are good when the object of study behaves variably, and the state of the system is determined by the position in which it is now located - this is an attempt to simulate chaotic development. "Chaos is a higher form of order, where harmony and haphazard impulses become the organizing principle." Chaos theory helps to understand the fractal nature of economic processes, characterizing the strategic behavior of a corporation [16].

So, H.-J. Warnecke considered the fractal as an independently acting structural unit of the organization [16].

At the same time, one of the main positive qualities of the fractal capital structure of a corporation is that a failure in one element will not entail serious negative consequences or a complete stop of the organization's activities. It will only serve as an indicator of the level of stability of the company, because with the overall well-being of the structure, there should be no obvious dissonance of its individual fragments [17].

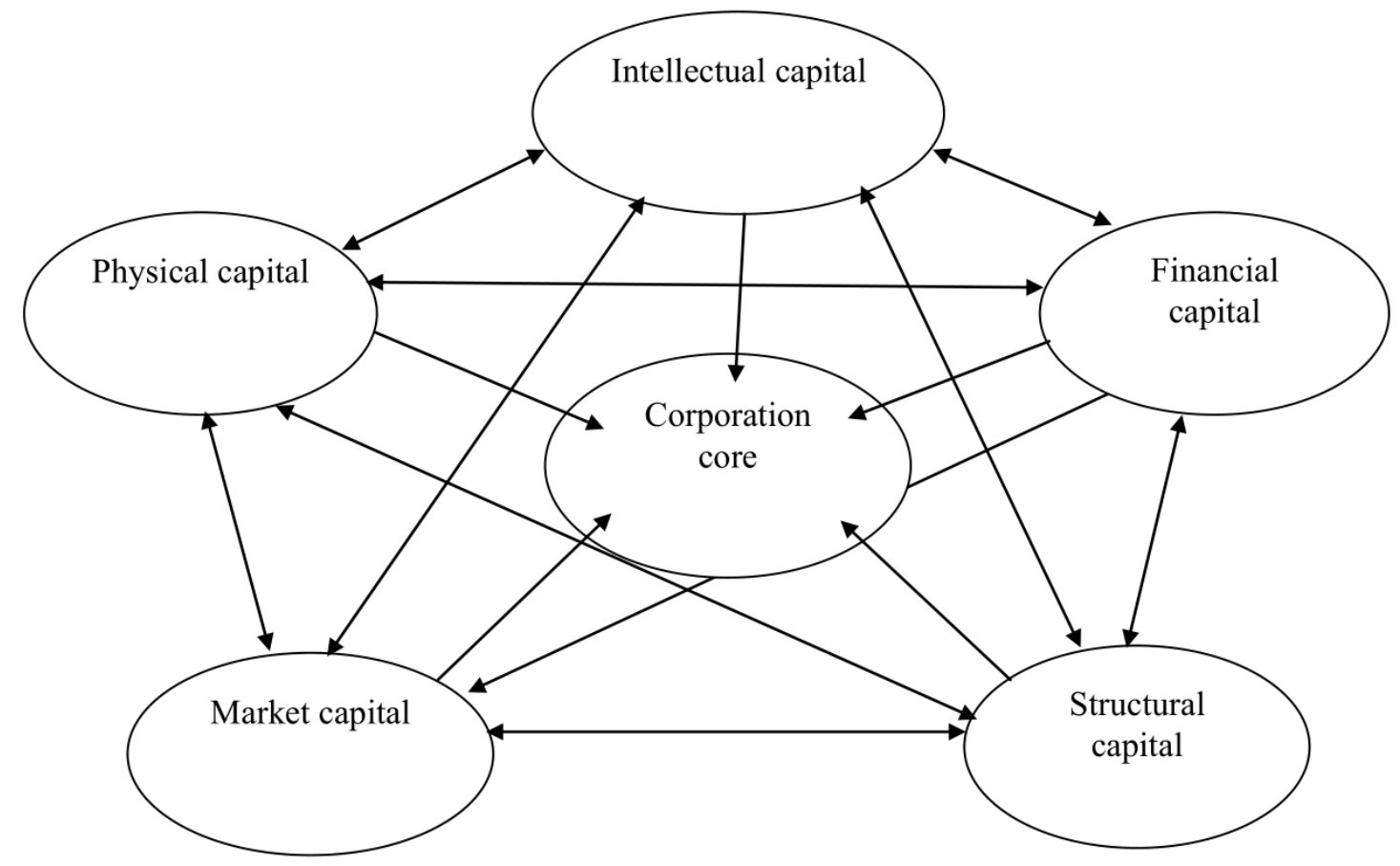

Fig. 3. Interaction of corporation capitals.

To study systems of this class - capitalograms, the method of fractal modeling is used. Mastering the techniques of constructing fractals and knowing the area of their application contribute to the study of strategizing processes in a modern economy [18].

\section{CONClusion}

In the corporation of the knowledge economy, the chaos of the elements of capital can be represented in the simplest form, for example, in the form of a geometric fractal, namely, the Pythagorean tree. However, this fractal will allow you to clearly see the capital structure in a static position. In order to present the total capital in practice in the form of any fractal model, it is necessary to choose the right software. Methods of system-cognitive analysis with a special software shell based on it - the domestic licensed software product "Eidos", are gaining popularity. Based on the data presented in tabular form, a fractal model of the total capital is built and experimental data are accumulated. Their processing showed that the selected form of presentation allows you to get a description of the total capital and present it in an easily visible form. The direction of further research is to create a method for synthesizing a capitalogram. 


\section{References}

[1] V.V. Ermolenko, Competitive advantages and capital formation of the corporation, Scientific Journal KubSAU. 2008. No. 37 URL: https://cyberleninka.ru/article/n/konkurentnyepreimuschestva-i-formirovanie-kapitalov-korporatsii (date of the application: 10.11.2020).

[2] G.B. Kleiner, System-integration theory of the enterprise and evolutionary approach, URL: http://kleiner.ru/sistemnointegratsionnaya-teoriya-predpriyatiya-i-evolyutsionnyiypodhod/ (date of the application: 10.11.2020).

[3] V.V. Ermolenko, D.V. Lanskaya, Capitalograms of the corporation," Economy and Entrepreneurship. 2013. No. 11-2 (40). P. 202-206.

[4] V. V. Radaev, The concept of capital, forms of capital and their conversion, Economic sociology. 2002. No. 4. P. 20-31.

[5] L.V. Davydova, S.A. Ilminskaya, Features of the formation of the capital structure of the enterprise, Finance and credit. 2007. No. 47 (287). P. 42-51

[6] D.V. Rozov, Evolutionary development of the theory of fixed capital, Finance and credit. 2007. No. 8. P. 52-73.

[7] V.V. Ermolenko, The core of capital of a modern corporation, Bulletin of the Adyghe State University. Series 5: Economics. 2009. No. 1. P. 19-22.

[8] T.A. Yakovets, Versatility of interpretations of the concept of "Capital" and its essence from the point of view of accounting (financial) accounting, International accounting. 2013. No. 28. P. 35-43.

[9] M.V. Bakhenskaya, Intellectual capital of the organization: methodological approaches to the definition, Bulletin of St. Petersburg University. Series 12. Psychology. Sociology. Pedagogy. 2011. No. 3. P. 280-285.

[10] D.V. Lanskaya, Mechanisms for harmonizing interests of subjects of corporate relations and resolving problems of development of Russian corporations, Creative Economy. 2013. No. 1. P. 126-132.

[11] L.I. Chernikova, A.V. Suvorov, Financial capital as a component of modern national capital, Russian Entrepreneurship. 2009. No. 9 (1). P. 31-35.

[12] V.V. Ermolenko, Strategic controlling in the management of the corporation's core capital, Scientific journal KubSAU. 2013. No. 87. P. 675-689.

[13] J.B. Clark, Distribution of wealth. Moscow: Economics, 1992.

[14] V.V. Ermolenko, D.V. Lanskaya, M.V. Zelinskaya, Configurations of corporation's capitals, Mediterranean Journal of Social Sciences. 2015. V. 6. № 5, P. 317-323.

[15] E. A. Sandryukova, E. E. Dubinina, Application of elements of the theory of fractals in the study of economic processes, Bulletin of economic security. 2017. No. 4. P. 349-352.

[16] E.V. Shkarupeta, V.A.Smyshlyaev, Fractal organizations in the knowledge economy, Vestnik VSTU. 2012. No. 7-1. P. 14-17.

[17] D.V. Lanskaya, K.V. Getmantsev, V.V., Ermolenko, The source of competitiveness of small innovative enterprises is in the competitive advantages of the innovation ecosystem of the University, The Future of the Global "Financial System: Downfall or Harmony: Part of the Lecture Notes in Networks and Systems book series" ISC 2018. Lecture Notes in Networks and Systems, Springer Nature Switzerland. Cham Elena G. Popkova E. (eds)

[18] D.V. Lanskaya, Y.I.Treschevsky, K.V.Getmantsev, T.A.Myasnikova, Strategizing as a Tool of Information and Analytical Provision and a Technology of Regional Development Management," The Future of the Global Financial System: Downfall or Harmony. ISC 2018. Lecture Notes in Networks and Systems: systems book series (LNNS). - Vol. 57. SpringSpringer Nature Switzerland AG 2019. Switzerland. 2019.
P. 348-356. DOI: doi.org/10.1007/978-3-030-00102-5_37. URL: http://apps.webofknowledge.com/f ... 00102-5_37 (date of the application: 10.11.2020). 